\title{
Computer-aided approach for design of tailor-made blended products
}

\author{
Yunus, Nor Alafiza; Gernaey, Krist; Woodley, John; Gani, Rafiqul
}

Publication date:

2012

Document Version

Publisher's PDF, also known as Version of record

Link back to DTU Orbit

Citation (APA):

Yunus, N. A., Gernaey, K., Woodley, J., \& Gani, R. (2012). Computer-aided approach for design of tailor-made blended products. Abstract from 3rd International Gas Processing Symposium, Doha, Qatar.

\section{General rights}

Copyright and moral rights for the publications made accessible in the public portal are retained by the authors and/or other copyright owners and it is a condition of accessing publications that users recognise and abide by the legal requirements associated with these rights.

- Users may download and print one copy of any publication from the public portal for the purpose of private study or research.

- You may not further distribute the material or use it for any profit-making activity or commercial gain

- You may freely distribute the URL identifying the publication in the public portal

If you believe that this document breaches copyright please contact us providing details, and we will remove access to the work immediately and investigate your claim. 


\title{
Computer-Aided Approach for Design of Tailor-Made Blended Products
}

\author{
Nor Alafiza Yunus, Krist V. Gernaey, John M. Woodley and \\ Rafiqul Gani*
}

Department of Chemical and Biochemical Engineering, Søltofts Plads, Building 229, Technical University of Denmark, 2800 Kgs. Lyngby, Denmark.

The majority of chemicals based products are mixtures of two or more substances. It is because a single chemical does not always satisfy the product needs. Mixing or blending is a simple process in chemical engineering, but using suitable chemical substances at right composition in a mixture is important in order to obtain the desired products. Blending process with the appropriate selection of the chemicals could offer advantages, such as, reducing the amount of fossil-fuel consumption and pollutants release to the atmosphere. Product safety and product attributes also could be enhanced by blending. However, the product performance may decline when other chemicals are added. In order to maintain/improve the blended product performance, it is necessary to identify the best product blend with the most appropriate chemicals. Finding the most appropriate chemicals is one of the challenges in chemical blending. The computer-aided approach is a fast and reliable methodology for identifying and selecting the chemicals. Therefore, a systematic computer-aided methodology for chemical blended product design is developed, to identify the most suitable chemicals for blending and formulate blended products that satisfy specific product needs.

In this paper, the systematic computer-aided methodology for product design is divided into four tasks. The first task is to define the design problem, where the product needs are identified, translated into target properties and given target values. In the second task, the required target property models are retrieved from a property model library developed specifically for this methodology. Then, a mixture/blend design algorithm is applied to obtain the mixtures/blends that match the set of constraints (design targets). This algorithm employs a decomposition based solution strategy to solve the mixture/blend problem. The result is a set of blends that match the constraints, the compositions, values of the target properties and information about their miscibility. Finally, the mixture target property values are verified either with experimental data (if available) or by means of rigorous models for the properties and mixtures that require it. The application of this systematic methodology is highlighted through case studies related to the design of blended gasoline and refrigerants, where the objective is to identify blended products that satisfy all the product attributes with at least similar or better performance compared to conventional products.

Keywords: computer-aided approach; chemical blends; product design; gasoline; refrigerant ${ }^{*}$ Corresponding author (Email: rag@kt.dtu.dk, Tel. +45 45252882, Fax: +45 45932906) 